\title{
$\underline{\text { Lung cancer stage-shift following a symptom awareness campaign }}$
}

\section{Authors:}

Martyn Kennedy*, MBChB

Affiliations: Leeds Teaching Hospitals NHS Trust

Address: St James University Hospital, Beckett Street, Leeds, LS9 7TF

Leanne Cheyne*, MBChB

Affiliations: Bradford Teaching Hospitals NHS Foundation Trust

Address: Bradford Royal Infirmary, Duckworth Lane, Bradford, BD9 6RJ

Michael Darby, FRCR

Affiliations: Leeds Teaching Hospitals NHS Trust

Address: St James University Hospital, Beckett Street, Leeds, LS9 7TF

Paul Plant, MD

Affiliations: Aintree University Hospital NHS Foundation Trust

Address: Dept of Thoracic Medicine, Aintree University Hospital, Liverpool, L9 7AL

Richard Milton, $M B C h B$

Affiliations: Leeds Teaching Hospitals NHS Trust

Address: St James University Hospital, Beckett Street, Leeds, LS9 7TF

Jonathan Robson, $M B C h B$

Affiliations: Leeds Teaching Hospitals NHS Trust

Address: St James University Hospital, Beckett Street, Leeds, LS9 7TF

Alison Gill, MBChB (hons)

Affiliations: York Hospitals NHS Foundation Trust

Address: York Hospital, Wigginton Road, York, YO31 8HE

Puneet Malhotra, MD

Affiliations: St Helens and Knowsley Teaching Hospitals NHS Trust

Address: Whiston hospital, Warrington Road, Prescot, Lancashire, L35 5DR

Victoria Ashford-Turner

Affiliations: Leeds Teaching Hospitals NHS Trust

Address: St James University Hospital, Beckett Street, Leeds, LS9 7TF

Kirsty Rodger, $M B C h B$

Affiliations: Leeds Teaching Hospitals NHS Trust

Address: St James University Hospital, Beckett Street, Leeds, LS9 7TF

Elankumaran Paramasivam, MD

Affiliations: Leeds Teaching Hospitals NHS Trust

Address: St James University Hospital, Beckett Street, Leeds, LS9 7TF

Annette Johnstone, FRCR

Affiliations: Leeds Teaching Hospitals NHS Trust

Address: Department of Clinical Radiology, St James University Hospital, Beckett Street, Leeds, LS9

$7 \mathrm{TF}$

Bobby Bhartia, MRCP, FRCR

Affiliations: Leeds Teaching Hospitals NHS Trust

Address: Department of Clinical Radiology, St James University Hospital, Beckett Street, Leeds, LS9 $7 \mathrm{TF}$ 
Shishir Karthik, FRCR

Affiliations: Leeds Teaching Hospitals NHS Trust

Address: Department of Clinical Radiology, St James University Hospital, Beckett Street, Leeds, LS9 $7 \mathrm{TF}$

Catherine Foster

Affiliations: NHS Leeds West Clinical Commissioning Group

Address: Unit 5-9, Wira House, West Park Ring Road, LS16 6EB

Veronica Lovatt

Affiliations: St Gemma's Hospice, previously Leeds Primary Care Trust

Address: St Gemma's Hospice, 329 Harrogate Road, Leeds, LS17 6QD

Francesca Hewitt, BA Hons

Affiliations: Leeds Teaching Hospitals NHS Trust

Address: Communications Office, St James's University Hospitals, Beckett Street, Leeds, LS9 7TF

Louise Cresswell, $M A$

Affiliations: Public Health, Leeds City Council previously Leeds Primary Care Trust

Address: Merrion House, Merrion Way, Leeds, LS2 8BB

Victoria H Coupland, PhD

Affiliations: National Cancer Registration and Analysis Service, Public Health England, London

Address: Zone A, $2^{\text {nd }}$ Floor, Skipton House, 80 London Road, London SE1 6LH

Margreet Lüchtenborg, PhD

Affilations: Cancer Epidemiology, Population and Global Health Programme, School of Cancer and Pharmaceutical Sciences, King's College London. National Cancer Registration and Analysis Service, Public Health England.

Address: Research Oncology, $3^{\text {rd }}$ Floor, Bermondsey Wing, Guy's Hospital, Great Maze Pond, London, SE1 9RT

Ruth H Jack, PhD

Affiliations: National Cancer Registration and Analysis Service, Public Health England, Nottingham. Address: Seaton House, London Road, Nottingham, NG2 4LA

Henrik Møller, Dr. Med.

Affiliations: School of Cancer and Pharmaceutical Sciences, King's College London

Address: Bermondsey Wing, Guy’s Hospital, Great Maze Pond, London, SE1 9RT

Matthew E Callister, PhD

Affiliations: Leeds Teaching Hospitals NHS Trust

Address: St James University Hospital, Beckett Street, Leeds, LS9 7TF

* These authors have contributed equally to the study

\section{Corresponding Author:}

Matthew E Callister, PhD, Leeds Teaching Hospitals NHS Trust

Address: Level 4, Gledhow Wing, St James University Hospital, Beckett Street, Leeds, LS9 7TF, United

Kingdom

Email: matthew.callister@nhs.net

Telephone: 01132066037

\section{Word count:}

3,931 


\begin{abstract}
$\underline{\text { Abstract }}$
Background.

Lung cancer outcomes in the UK are worse than in many other developed nations. Symptom awareness campaigns aim to diagnose patients at an earlier stage to improve cancer outcomes.
\end{abstract}

Methods.

An early diagnosis campaign for lung cancer commenced in Leeds, UK in 2011 comprising public and primary-care facing components. Rates of community-referral for chest X-ray, and lung cancer stage (TNM seventh edition) at presentation were collected from 2008 to 2015. Linear trends were assessed by $\chi^{2}$ test for trend in proportions. Headline figures are presented for the three years pre-campaign (2008-2010) and the three most recent years for which data is available during the campaign (20132015).

Findings.

Community-ordered chest X-ray rates per year increased from 18,909 in 2008-2010 to 34,194 in 2013$2015(80.8 \%$ increase $)$. A significant stage shift towards earlier stage lung cancer was seen $\left(\chi^{2}(1)=32 \cdot 2\right.$, $\mathrm{p}<0.0001)$. There was an 8.8 percentage point increase in the proportion of patients diagnosed with stage I/II lung cancer (26.5\% pre-campaign vs. $35.3 \%$ during campaign) and a $9.3 \%$ reduction in the absolute number of patients diagnosed with stage III/IV disease (1,254 pre-campaign vs. 1,137 during campaign).

Interpretation.

This is the largest described lung cancer stage-shift in association with a symptom awareness campaign. A causal link between the campaign and stage-shift cannot be proven but appears plausible. Limitations of the analysis include a lack of contemporary control population.

Funding.

UK National Awareness and Early Diagnosis Initiative, Leeds Primary Care Trust, Leeds Clinical Commissioning Groups, Leeds City Council.

Word count $=243$ 


\section{$\underline{\text { Key messages }}$}

\section{What is the key question?}

Can symptom awareness campaigns for lung cancer lead to meaningful improvements in lung cancer outcomes?

\section{What is the bottom line?}

A large and sustained increase in community ordered chest X-rays and significant stage-shift in lung cancer have been observed alongside a prolonged symptom awareness campaign; a causal link cannot be proven but appears plausible.

\section{Why read on?}

This is the largest stage-shift in lung cancer to be described outside a screening trial, and suggests benefit to continued symptom awareness campaigns as one strategy to improve lung cancer outcomes. 


\section{Introduction}

A series of international comparisons have consistently demonstrated worse outcomes for patients diagnosed with lung cancer in the UK compared with other developed nations. ${ }^{1-4}$ The International Cancer Benchmarking Partnership showed an adverse stage distribution in the UK compared with elsewhere, suggesting that delayed diagnosis may contribute to these poorer outcomes. ${ }^{5}$ In 2008 , the UK Government and Cancer Research UK launched the National Awareness and Early Diagnosis Initiative (NAEDI) with the aim of achieving earlier cancer diagnosis to improve outcomes. ${ }^{6}$ A number of regional initiatives were funded and in 2012-2013 nationwide advertising campaigns sought to raise public awareness of early symptoms of common cancers, with the aim of increasing diagnosis of early stage cancers, and reducing the proportion of patients diagnosed following emergency presentation (known to be associated with poor outcomes). ${ }^{7,8}$ This study assessed lung cancer outcomes following a coordinated public awareness campaign and primary care educational programme in Leeds, UK originally funded by NAEDI. The primary outcomes of the campaign were the number of communityordered chest X-rays (CXRs) performed and the stage distribution of lung cancer cases. Secondary endpoints included route to diagnosis (including proportion diagnosed following emergency presentation), performance status, cancer treatment rates, and lung cancer survival and mortality.

\section{Methods}

This was a time-trend study, reviewing outcomes for patients diagnosed with lung cancer first seen at Leeds Teaching Hospitals (LTH) for the three years prior to initiation of the campaign (2008-2010), and for the five years over which the campaign has run for which data is available (2011-2015). The early diagnosis campaign comprising the four elements described below commenced in January 2011 and has continued in various forms to date.

First, a primary care health professional educational package highlighting the UK National Institute for Health and Clinical Excellence criteria for CXR referral (Clinical Guideline 24, 2005) ${ }^{9}$ and the importance of early lung cancer detection was delivered to general practitioners (GPs), community nurses/matrons, and community pharmacists in Leeds (21 presentations between 2011 and 2014). Second, a marketing communications campaign was developed including advertisements on buses and bus shelters, a targeted leaflet drop to 80,000 households, branded beer mats at pubs and working men's clubs, branded pharmacy bags, and radio advertisements. The campaign initially targeted areas of high deprivation and lung cancer incidence in Inner East and Inner South Leeds, but subsequent communications were widened to include the whole city. The strapline for the campaign was "Got a cough? Get a check", with subsequent advice stating "If you have a cough, breathlessness or chest pain for over three weeks, you need a chest x-ray to rule out serious lung problems". Third, a team of community health educators delivered key messages to local target populations including recognition of respiratory symptoms, understanding that early diagnosis can lead to better outcomes, and highlighting ways of accessing CXRs. Finally, a self-request CXR service was established for patients aged 50 years and over with respiratory symptoms lasting 3 weeks or longer who had not had a CXR within the last three months. The referring clinician was the respiratory physician who produced the criteria; radiographers checked patients' eligibility against these criteria and performed a posterioranterior CXR if appropriate. Patients were referred back to their GP or recalled for further investigation with CT scan if required.

The number of community-ordered CXRs in Leeds (both GP-requested and self-requested CXRs) was extracted from the LTH radiology database. Outcome data for patients first seen at LTH with a new diagnosis of lung cancer between January 2008 and December 2015 were collected from both National Lung Cancer Audit (NLCA) submissions and the National Cancer Registration and Analysis Service (NCRAS) at Public Health England. Electronic records for cases identified by NCRAS which had not been included in LTH NLCA cohort were individually reviewed to check that they represented lung cancer first seen at LTH. Cases were excluded from analysis if there was definite pathological evidence of an alternative (non-lung) cancer primary site, lung cancer was thought unlikely following discussion at a cancer multi-disciplinary team (MDT) meeting, or if the patient was first seen at a peripheral hospital and referred to LTH for treatment. To avoid bias, cases where there was no information about 
a cancer diagnosis available, or where the lung cancer diagnosis was questionable but the case had not been discussed at a cancer MDT remained in the cohort for analysis. Since 2015, both NLCA and NCRAS have derived data from a single national cancer dataset, the Cancer Outcome and Service Dataset (COSD). This is now the national standard for reporting all cancer activity in the National Health Service in England, with the result that the NLCA and NCRAS datasets should now be identical. $^{10}$

The following information was recorded: sex; age; index of multiple deprivation (derived from postcode); WHO performance status; TNM stage; pathological subtype; route to diagnosis; treatment; date first seen; diagnosis date; date of death or censor. Cases were grouped by year according to date of diagnosis. All cases diagnosed in 2008 and 2009 were restaged according to the TNM seventh edition to allow comparison of stage distribution over the course of the campaign. For synchronous lung cancers, the stage of the most advanced cancer was recorded. Patients with a second metachronous lung cancer diagnosed during the study period (following MDT review) were counted twice in the analysis. Routes to diagnosis were manually extracted for all cases and categorised as emergency presentation, respiratory clinic referral, intrahospital referral (referral from other specialties within LTH where the lung cancer diagnosis was considered incidental to presenting episode) or other (mostly radiological follow-up of pneumonia or pulmonary nodules). Treatments were classified as surgical resection, radical oncology (conventionally fractionated radical radiotherapy, stereotactic ablative body radiotherapy (SABR) or concurrent chemoradiation), palliative oncology (palliative chemotherapy, palliative radiotherapy, or a combination of both) or best supportive care. Lung cancer mortality data were obtained from the Office for National Statistics. The numbers of deaths and age standardised mortality rates (with 95\% CIs) where the underlying cause was lung cancer (ICD-10 C33-C34) were provided for England and Wales, and Leeds from 2008 until 2016. Figures for Leeds are based on the boundaries of three Leeds Clinical Commissioning Groups as of May 2017. Figures are based on deaths registered rather than deaths occurring in each calendar year, and age standardised rates per 100,000 population were standardised to the 2013 European Standard Population.

Changes over the eight calendar years in patient characteristics, tumour characteristics, referral pathway, treatment, and 1-year survival were assessed by a one degree of freedom (df) $\chi^{2}$ test for rend in proportions. Missing value (unknown) categories were not included in these tests. For pathological subtype, referral pathway and treatment, where the categories are not an ordered sequence, several $1 \mathrm{df}$ tests were calculated, each test comparing one specific category with the aggregate of the other specified categories. For treatment, the test compared radical treatment (surgical resection or radical oncological treatment) versus the other categories. Baseline data were collected over a 3-year period prior to initiation of the campaign (2008-2010). Headline figures are compared with the most recent three year period for which data are available (2013-2015, termed established campaign).

The study was registered with the UK Clinical Research Network Study Portfolio (UKCRN ID 9447) and received ethics committee approval (MREC No 10/H1302/81).

\section{Role of the funding source}

The campaign was funded by NAEDI (UK Department of Health; co-chaired by Cancer Research UK) 2011, NHS Leeds Primary Care Trust (2011-2013), the three Leeds Clinical Commissioning Groups (2013-current) and Leeds City Council (2013-current). NAEDI, the UK Department of Health, Cancer Research UK and Leeds City Council had no role in study design, data collection, interpretation, analysis, nor in the writing and submitting process. Co-authors employed by the Primary Care Trust and Clinical Commissioning Groups were members of the early diagnosis campaign team, and have been involved in study design, interpretation of data, report writing and the decision to submit for publication.

\section{Results}

Annual community referrals for CXR (subdivided between GP and self-request routes) are shown in Table 1 . There was an $80.8 \%$ increase in annual referrals comparing pre-campaign with the period 
during the established campaign (18,909 in 2008-2010 vs 34,194 in 2013-2015). Monthly community referrals for CXR are shown in Figure 1. Peaks in CXR requests were seen following GP educational events (January 2011, September 2011, November 2013), and following the national TV advertising campaign which ran in April-May 2012.

A total of 5,800 lung cancer cases were identified from NLCA and NCRAS with diagnosis dates between January 2008 and December 2015, and a flow chart is shown in Figure 2. Cases excluded from analysis were as follows: 323 cases with pathological confirmation of alternative cancer; 20 cases thought unlikely to be cancer following discussion at a cancer MDT; and 698 cases listed as first seen at LTH but referred from peripheral centres. There were 15 cases with no information relating to a cancer diagnosis on our electronic record, and 31 cases where lung cancer was thought questionable but which had not been discussed at a cancer MDT. These 46 cases were included for analysis (data recorded as unknown where appropriate). A total of 58 metachronous primary lung cancers were diagnosed during the study period. The total number of lung cancer cases in the cohort for analysis was 4,759 .

Demographic details and performance status of patients diagnosed with lung cancer at LTH are shown in Table 2. There were 577 diagnoses per year pre-campaign (2008-2010) and 590 per year during the established campaign (2013-2015). A peak in diagnoses occurred during the transition period in 2012 when 649 diagnoses were made - a 12.5\% increase in the number of cases. There were no significant trends in sex distribution, age, or performance status over the study period. There was a reduction in the proportion of patients from the most deprived quintile and a corresponding increase in patients from the least deprived quintile over the course of the study $\left(\chi^{2}(1)=9 \cdot 6 ; p=0 \cdot 002\right)$.

Stage distribution is shown in Table 3, and demonstrates a stage-shift towards earlier stage disease during the campaign $\left(\chi^{2}(1)=32 \cdot 2 ; \mathrm{p}<0.0001\right)$. There was an 8.8 percentage point increase in the proportion of patients diagnosed with stage I/II disease (from 26.5\% in 2008-2010 to 35.3\% in 20132015) and a corresponding 8.2 percentage point decrease in the proportion of patients diagnosed with stage III/IV disease (from $72.4 \%$ in $2008-2010$ to $64.2 \%$ in $2013-2015$ ). Furthermore there was a $9.3 \%$ reduction in the absolute number of patients diagnosed with stage III/IV disease comparing periods precampaign and during the established campaign (1,254 in 2008-2010 vs 1,137 in 2013-2015). A change in pathological subtype was also observed, mainly related to a reduction in the proportion of cases classified as non-small cell lung cancer not otherwise specified (NSCLC NOS) ( $p<0 \cdot 0001)$. A smaller reduction was observed in the proportion of patients without pathological confirmation of lung cancer, again reflecting national trends. This may have contributed to corresponding increases in the proportion of other groups.

Route to diagnosis and treatment data are shown in Table 4. There were significant reductions in the proportion of patients diagnosed following emergency presentation and by intrahospital referral, with corresponding increases in the proportion diagnosed following clinic referral and by other routes such as pulmonary nodule follow-up ( $<00.0001$ for all linear trends). Comparing the pre-campaign period with the period during the established campaign, there was a 7.2 percentage point reduction in emergency presentation (from $36.0 \%$ to $28.8 \%$ respectively). The proportion of patients receiving radical therapy for lung cancer (surgery and radical oncology treatments combined) increased during the campaign $\left(\chi^{2}(1)=60 \cdot 6 ; p<0 \cdot 0001\right)$. There was a reciprocal fall in the proportion of patients who received best supportive care. The trend to increased radical oncology treatments was apparent prior to the campaign starting, and largely reflects the increased use of SABR and concurrent chemoradiation (data not shown).

One year survival increased during the campaign from $31.8 \%$ for $2008-2010$ to $40 \cdot 3 \%$ in $2013-2015$ $\left(\chi^{2}(1)=26 \cdot 0 ; p<0 \cdot 0001\right.$ - Table 5). Table 6 and Figure 3 show mortality data for lung cancer in Leeds and England and Wales (total deaths and age-standardised mortality rates) between 2008 and 2016 (the last year for which data are available). ${ }^{11}$ Age-standardised mortality rates for lung cancer decreased in Leeds as well as in England and Wales over this period. The decrease over time was stronger in Leeds than in England and Wales both in absolute terms ( 17.7 vs. $7 \cdot 5$ per 100,000 respectively) and in relative terms (rate ratio 2016/2008: 0.81 vs. $0 \cdot 88$ respectively). 


\section{Discussion}

The primary end points of this study were the number of community-ordered CXRs and the stage distribution of lung cancers first seen at LTH. The interventions comprising the lung cancer campaign had a large, sustained effect on community CXR referrals, with an $80.8 \%$ increase comparing the precampaign period and the period during the established campaign. The campaign comprised interventions targeting the public and health professionals, and coincided with a nationwide media campaign (Be Clear on Cancer) during 2012 and 2013. It is therefore impossible to attribute the rise in CXR referrals to any specific component of the local campaign and similarly we are unable to discriminate between the effects of the local and national interventions as they ran over the same time period. Nevertheless, three rounds of GP education events were each followed by surges in CXR referrals suggesting that an alteration in the threshold for CXR referral by GPs may have made an important contribution to the overall increase. Analysis of GP attendance data over this period would allow an opportunity to discriminate between changes in GP and patient behaviour. This is an area for future research, but these data were not available for the analysis presented here. This increase in CXR referrals coincided with a stage-shift of lung cancer presentation to a more favourable stage distribution. Due to the nature of the study, it is not possible to prove a causal link between the increase in CXR referrals and stage-shift. However, a relationship between these two events does seem plausible in the absence of any other likely confounding factor.

Overdiagnosis occurs when an intervention results in detection of cancers that would not otherwise have become apparent during a patient's lifetime. Whilst this is most commonly considered in the context of screening, other interventions to promote earlier diagnosis of cancer such as symptom awareness campaigns may also be subject to overdiagnosis. Overdiagnosed cases tend to be early stage, and may therefore reduce the proportion of patients diagnosed with late-stage disease by increasing the total number of diagnoses (and therefore the denominator for this proportion). A reduction in the absolute number of advanced cancers is therefore the preferred parameter for judging the true benefit of an intervention aimed at earlier diagnosis of cancer. Thus the demonstration of a $9.3 \%$ reduction in the number of patients diagnosed with stage III/IV lung cancer from 1,254 in the pre-campaign period (2008-2010) to 1,137 during the established campaign (2013-2015) is an important finding that would suggest such a beneficial effect of this intervention unrelated to overdiagnosis.

The fact that annual lung cancer diagnoses returned to near baseline rates would also tend to suggest that overdiagnosis was minimal. Assuming that a sustained increase in CXR referral rates is necessary to maintain earlier diagnosis, an increase in the number of CXRs per cancer diagnosed would be anticipated, and was demonstrated in the data presented here.

The shift towards earlier stage disease was accompanied by a reduction in the proportion of lung cancer cases diagnosed following emergency presentation to secondary care. Emergency presentation of lung cancer is recognised as a poor patient experience and is associated with worse outcomes which likely reflect case mix factors such as stage and performance status. ${ }^{7,8}$ The definitions used for route to diagnosis did not match those subsequently published by NCRAS and thus limits comparison with national data. For example, LTH commenced a direct to CT pathway during the study, which significantly reduced the number of formal 2-week-wait referrals and thus all outpatient referrals were considered as a single group in the data presented here. The reduction in the proportion of patients diagnosed with NSCLC not otherwise specified cases has been widely observed elsewhere in the UK, ${ }^{12}$ and is driven by advances in systemic therapy requiring sub-classification of NSCLC where possible. Assessment of lung cancer treatment rates over the course of the study are limited by evolving oncological practice unrelated to the interventions described here. The introduction of SABR in Leeds in 2009 and the increased use of concurrent chemoradiation over this period may confound survival and mortality analysis in this study.

A reduction in the number and percentage of lung cancer patients from the most deprived quintile was observed. Interestingly though, there was no difference in stage distribution between the five index of multiple deprivation (IMD) quintiles (data not shown) across the whole study period. Furthermore, an 
increase in the proportion of patients diagnosed with early stage disease was observed in all IMD quintiles during the campaign (data not shown). Thus, if a causal link does exist between the awareness campaign, CXR rates and lung cancer stage distribution, this relationship appears to be independent of deprivation. There was no significant change in deprivation or age distribution in the population with the Leeds City Council boundary during the study (data not shown).

An assessment of a six week UK nationwide lung cancer public awareness campaign in 2012 also showed an increase in the number of GP-referred CXRs $(18.6 \%$ increase, $p<0.001)$ and in the proportion of patients diagnosed with stage I NSCLC $(3 \cdot 1$ percentage point increase, $p<0.001)$ in a three month period (comprising the campaign and immediate aftermath) compared to earlier control periods. ${ }^{13}$ The larger increase in community-referrals for CXR $(80.8 \%)$ and in Stage I disease (8.1 percentage points) described here may relate to the more sustained nature of interventions in Leeds over several years and longer follow-up time. Considering national trends over longer time periods, a reduction in the proportion of lung cancer cases diagnosed following emergency presentation has been observed across England (39\% in 2006, 34\% in 2013). ${ }^{14}$ Furthermore, 1-year lung cancer survival has improved nationally since 2008 , with a peak annual improvement of $2.2 \%$ per annum for patients diagnosed in 2010-2012. ${ }^{15}$ The cause of these trends is likely to be multifactorial, but may reflect alterations in treatment (increased lung cancer resection rates, introduction of new radiotherapy techniques and systemic treatments) as well as possible earlier diagnosis prompted by nationwide awareness campaigns. Comparisons with stage distribution of lung cancer nationally are limited by incomplete stage data, and previous recording of small cell lung cancer (SCLC) according to limited or extensive stage rather than using the TNM classification. Data from NLCA (personal communication Professor Richard Hubbard, Dr Aamir Khakwani) and NCRAS for 2011-2016 are shown in Table 7. The number of lung cancer cases diagnosed at stage I/II as a proportion of all those with a TNM (seventh edition) stage at LTH compared with national data from NLCA and NCRAS are shown in Figure 4. However, these comparisons should be made with caution, as these data may not truly reflect overall stage distribution due to bias relating to exclusion of SCLC and unstaged cases. The proportion of unstaged cases from 2011 NCRAS data is particularly high (28.2\%), which may limit the robustness of this comparison but has been retained for completeness. The 2016 data for LTH were taken directly from the NLCA 2017 annual report, ${ }^{16}$ and have not been subject to individual case review as occurred for LTH data from 2008-2015. No statistical comparison has been made, but there appears to be a divergence between Leeds and national data from 2013 onwards.

The US Prostate Lung Colorectal and Ovarian study (PLCO) demonstrated no mortality reduction and only a small stage-shift in lung cancer diagnoses (4.6 percentage point increase in stage I diagnoses) following yearly CXR screening for lung cancer. ${ }^{17}$ Whilst there are clear differences between PLCO and this study both in design (screening versus early symptomatic detection) and staging data (PLCO used TNM fifth edition with SCLC cases recorded separately), the larger stage-shift demonstrated here merits comment. The proportion of patients in Leeds diagnosed with stage I disease increased by $8 \cdot 1$ percentage points from $17.0 \%$ to $25.1 \%$ following the early diagnosis campaign, but this is still less than the proportion of patients with stage I disease in the usual care (i.e. unscreened) arm of PLCO (27.1\%). The possible beneficial effect of increased referral for CXR in our study may therefore reflect the more adverse stage distribution of lung cancer in our baseline state compared to the usual care arm of the PLCO study.

Analysis of lung cancer survival over the course of the campaign is subject to biases (lead-time and overdiagnosis) and the confounding effects of evolving oncological therapy. Assessment of mortality avoids lead-time phenomenon and overdiagnosis, but is still confounded by changes in treatment unrelated to the campaign. Age-standardised mortality rates for lung cancer were significantly higher in Leeds than England and Wales prior to the campaign. These rates reduced in both areas over the course of the campaign, more strongly so in Leeds.

The relationship between respiratory symptoms and subsequently diagnosed cancer has been recently studied. An analysis of a UK-based case-control study ${ }^{18}$ estimated a symptom lead time for lung cancer of only two to three months. ${ }^{19}$ The authors argue that expediting a diagnosis by this interval may not be sufficient to result in a stage-shift, and thus any stage-shift demonstrated in the context of a symptom 
awareness campaign may instead reflect the incidental diagnosis of lung cancer in patients with symptoms of other causes. This maybe the mechanism for the stage-shift demonstrated here.

The strengths of this study are the sustained and multifaceted nature of the early diagnosis campaign, and the comprehensive staging data including historical controls restaged according to a contemporary system to allow assessment of time trends. Furthermore, the very large increase in community-ordered CXRs over a 5-year period allows an unprecedented assessment of possible effects on increased use of CXR in response to respiratory symptoms on lung cancer characteristics and outcomes. There are several important weaknesses to this study. First, it took place in a single city, which limits the generalisability of the study results. Replication of these findings in other locations is needed to assess external validity. Second, there was no contemporary control population; similar nationwide early diagnosis campaigns over the period of our intervention preclude the use of other parts of England as uncontaminated control areas, and limitations of national data are discussed previously. Third, the study design means that no direct causal link can be drawn between the increase in rate of CXR referrals and any studied lung cancer parameter. Fourth, there are confounding factors such as evolving oncological practice which are likely to influence lung cancer outcomes. Finally, any survival effect demonstrated may simply reflect a lead-team phenomenon.

In summary, this study demonstrates a large increase in community CXR referral rates in response to a public and health professional-facing lung cancer symptom awareness campaign. An increase in the proportion of lung cancer patients diagnosed with early stage disease, and importantly a reduction in the actual number of cases diagnosed with advanced disease have been observed. A causal link between these observations cannot be proven but appears plausible. Further analyses will include health economic evaluation of the interventions described and ongoing review to assess whether these changes result in a significant reduction in lung cancer-specific mortality in Leeds over coming years.

Word count $=3,986$ 


\section{Author contributions}

Conception and design of study: MD, RR, PP, RM, CF, VL, FH, VHC, LCr, ML, RJ, HM, MEC

Acquisition of data: MK, LCh, MD, RR, PP, RM, JR, AG, PM, VAT, KR, EP, AJ, BB, SK, MEC

Analysis of data: MK, LCh, VHC, ML, RJ, HM, MEC

Interpretation of data: $\mathrm{MK}, \mathrm{LCh}, \mathrm{MD}, \mathrm{VHC}, \mathrm{ML}, \mathrm{RJ}, \mathrm{HM}, \mathrm{MEC}$

Drafting the work or revising critically for important intellectual content: All authors

Final approval of version to be published: All authors

Agreement to be accountable for all aspects of the work in ensuring that questions related to the accuracy or integrity of any part of the work are appropriately investigated and resolved: All authors.

\section{Declaration of interests}

None of the authors have any conflict of interests to declare.

\section{Acknowledgements}

We acknowledge the contributions of Dr Jon Fear and Ms Brenda Fullard (formerly Consultants in Public Health with NHS Leeds Primary Care Trust), and Dr Rod Robertson (formerly Consultant Radiologist at Leeds Teaching Hospitals) for their input into this project. We also acknowledge the contribution of the whole of the Leeds Lung Cancer Multi-Disciplinary Team. 


\begin{tabular}{|l|c|c|c|c|c|c|c|c|}
\hline & \multicolumn{3}{|c|}{ Pre-campaign } & \multicolumn{2}{c|}{ Early campaign } & \multicolumn{2}{c|}{ Established campaign } \\
\hline Year & 2008 & 2009 & 2010 & 2011 & 2012 & 2013 & 2014 & 2015 \\
\hline GP requested CXRs & 17,673 & 18,804 & 20,251 & 26,764 & 33,959 & 29,570 & 34,606 & 33,531 \\
\hline Self-request CXRs & 0 & 0 & 0 & 2516 & 1617 & 2519 & 1536 & 821 \\
\hline $\begin{array}{l}\text { Total community- } \\
\text { ordered CXRs }\end{array}$ & 17,673 & 18,804 & 20,251 & 29,280 & 35,576 & 32,089 & 36,142 & 34,352 \\
\hline
\end{tabular}

Table 1: Community-ordered chest X-ray rates at Leeds Teaching Hospitals from 2008-2015 


\begin{tabular}{|c|c|c|c|c|c|c|c|c|}
\hline \multirow[b]{2}{*}{$\begin{array}{l}\text { Year of lung cancer } \\
\text { diagnosis }\end{array}$} & \multicolumn{3}{|c|}{ Pre-campaign } & \multicolumn{2}{|c|}{ Early campaign } & \multicolumn{3}{|c|}{ Established campaign } \\
\hline & 2008 & 2009 & 2010 & 2011 & 2012 & 2013 & 2014 & 2015 \\
\hline $\begin{array}{l}\text { Total lung cancer } \\
\text { diagnoses }\end{array}$ & 577 & 576 & 578 & 608 & 649 & 574 & 589 & 608 \\
\hline \multicolumn{9}{|l|}{ Sex } \\
\hline Male. & $\begin{array}{c}299 \\
(51 \cdot 8) \\
\end{array}$ & $\begin{array}{c}295 \\
(51 \cdot 2) \\
\end{array}$ & $\begin{array}{c}301 \\
(52 \cdot 1)\end{array}$ & $\begin{array}{c}299 \\
(49 \cdot 2)\end{array}$ & $\begin{array}{c}330 \\
(50 \cdot 8) \\
\end{array}$ & $\begin{array}{c}295 \\
(51 \cdot 4)\end{array}$ & $\begin{array}{c}276 \\
(46 \cdot 9) \\
\end{array}$ & $\begin{array}{c}288 \\
(47 \cdot 4)\end{array}$ \\
\hline Female & $\begin{array}{c}278 \\
(48 \cdot 2)\end{array}$ & $\begin{array}{c}281 \\
(48 \cdot 8)\end{array}$ & $\begin{array}{c}277 \\
(47 \cdot 9)\end{array}$ & $\begin{array}{c}309 \\
(50 \cdot 8)\end{array}$ & $\begin{array}{c}319 \\
(49 \cdot 2)\end{array}$ & $\begin{array}{c}279 \\
(48 \cdot 6)\end{array}$ & $\begin{array}{c}313 \\
(53 \cdot 1)\end{array}$ & $\begin{array}{c}320 \\
(52 \cdot 6)\end{array}$ \\
\hline \multicolumn{9}{|c|}{ Linear trend: $\chi^{2}(1)=4 \cdot 01 ; \mathrm{p}=0 \cdot 05$} \\
\hline \multicolumn{9}{|l|}{ Age } \\
\hline$<55 \mathrm{yrs}$ & $\begin{array}{c}43 \\
(7 \cdot 5) \\
\end{array}$ & $\begin{array}{c}36 \\
(6 \cdot 3) \\
\end{array}$ & $\begin{array}{c}28 \\
(4 \cdot 8)\end{array}$ & $\begin{array}{c}36 \\
(5 \cdot 9)\end{array}$ & $\begin{array}{c}40 \\
(6 \cdot 2)\end{array}$ & $\begin{array}{c}33 \\
(5 \cdot 7)\end{array}$ & $\begin{array}{c}39 \\
(6 \cdot 6)\end{array}$ & $\begin{array}{c}32 \\
(5 \cdot 3)\end{array}$ \\
\hline $55-59 \mathrm{yrs}$ & $\begin{array}{c}26 \\
(4 \cdot 5)\end{array}$ & $\begin{array}{c}38 \\
(6 \cdot 6)\end{array}$ & $\begin{array}{c}31 \\
(5 \cdot 4)\end{array}$ & $\begin{array}{c}35 \\
(5 \cdot 8) \\
\end{array}$ & $\begin{array}{c}37 \\
(5 \cdot 7)\end{array}$ & $\begin{array}{c}43 \\
(7 \cdot 5)\end{array}$ & $\begin{array}{c}35 \\
(5 \cdot 9)\end{array}$ & $\begin{array}{c}32 \\
(5 \cdot 3)\end{array}$ \\
\hline $60-64 y r s$ & $\begin{array}{c}53 \\
(9 \cdot 2) \\
\end{array}$ & $\begin{array}{c}72 \\
(12 \cdot 5) \\
\end{array}$ & $\begin{array}{c}71 \\
(12 \cdot 3) \\
\end{array}$ & $\begin{array}{c}60 \\
(9 \cdot 9) \\
\end{array}$ & $\begin{array}{c}56 \\
(8 \cdot 6) \\
\end{array}$ & $\begin{array}{c}66 \\
(11 \cdot 5) \\
\end{array}$ & $\begin{array}{c}56 \\
(9 \cdot 5) \\
\end{array}$ & $\begin{array}{c}70 \\
(11 \cdot 5) \\
\end{array}$ \\
\hline $65-69 y r s$ & $\begin{array}{c}90 \\
(15 \cdot 6) \\
\end{array}$ & $\begin{array}{c}93 \\
(16 \cdot 1) \\
\end{array}$ & $\begin{array}{c}66 \\
(11.4) \\
\end{array}$ & $\begin{array}{c}94 \\
(15 \cdot 5) \\
\end{array}$ & $\begin{array}{c}87 \\
(13 \cdot 4) \\
\end{array}$ & $\begin{array}{c}95 \\
(16 \cdot 6) \\
\end{array}$ & $\begin{array}{c}80 \\
(13 \cdot 6) \\
\end{array}$ & $\begin{array}{c}116 \\
(19 \cdot 1) \\
\end{array}$ \\
\hline $70-74 y r s$ & $\begin{array}{c}106 \\
(18 \cdot 4)\end{array}$ & $\begin{array}{c}92 \\
(16 \cdot 0)\end{array}$ & $\begin{array}{c}116 \\
(20 \cdot 1)\end{array}$ & $\begin{array}{c}109 \\
(17 \cdot 9)\end{array}$ & $\begin{array}{c}123 \\
(19 \cdot 0)\end{array}$ & $\begin{array}{c}89 \\
(15 \cdot 5)\end{array}$ & $\begin{array}{c}109 \\
(18 \cdot 5)\end{array}$ & $\begin{array}{c}95 \\
(15 \cdot 6)\end{array}$ \\
\hline $75-79 y r s$ & $\begin{array}{c}108 \\
(18 \cdot 7) \\
\end{array}$ & $\begin{array}{c}96 \\
(16 \cdot 7) \\
\end{array}$ & $\begin{array}{c}112 \\
(19 \cdot 4)\end{array}$ & $\begin{array}{c}114 \\
(18 \cdot 8) \\
\end{array}$ & $\begin{array}{c}130 \\
(20 \cdot 0) \\
\end{array}$ & $\begin{array}{c}98 \\
(17 \cdot 1) \\
\end{array}$ & $\begin{array}{c}107 \\
(18 \cdot 2) \\
\end{array}$ & $\begin{array}{c}110 \\
(18 \cdot 1) \\
\end{array}$ \\
\hline$\geq 80 \mathrm{yrs}$ & $\begin{array}{c}151 \\
(26 \cdot 2) \\
\end{array}$ & $\begin{array}{c}149 \\
(25 \cdot 9) \\
\end{array}$ & $\begin{array}{c}154 \\
(26 \cdot 6) \\
\end{array}$ & $\begin{array}{c}160 \\
(26 \cdot 3) \\
\end{array}$ & $\begin{array}{c}176 \\
(27 \cdot 1) \\
\end{array}$ & $\begin{array}{c}150 \\
(26 \cdot 1) \\
\end{array}$ & $\begin{array}{c}163 \\
(27 \cdot 7) \\
\end{array}$ & $\begin{array}{c}153 \\
(25 \cdot 2) \\
\end{array}$ \\
\hline \multicolumn{9}{|c|}{ Linear trend: $\chi^{2}(1)=0.00 ; p=0.97$} \\
\hline \multicolumn{9}{|c|}{ Index of multiple deprivation } \\
\hline $\begin{array}{l}\text { IMD quintile } 1 \\
\text { (most deprived) }\end{array}$ & $\begin{array}{c}253 \\
(43 \cdot 8) \\
\end{array}$ & $\begin{array}{c}237 \\
(41 \cdot 1) \\
\end{array}$ & $\begin{array}{c}232 \\
(40 \cdot 1) \\
\end{array}$ & $\begin{array}{c}232 \\
(38 \cdot 2) \\
\end{array}$ & $\begin{array}{c}230 \\
(35 \cdot 4) \\
\end{array}$ & $\begin{array}{c}215 \\
(37 \cdot 5) \\
\end{array}$ & $\begin{array}{c}217 \\
(36 \cdot 8) \\
\end{array}$ & $\begin{array}{c}224 \\
(36 \cdot 8) \\
\end{array}$ \\
\hline IMD quintile 2 & $\begin{array}{c}115 \\
(19 \cdot 9)\end{array}$ & $\begin{array}{c}121 \\
(21 \cdot 0)\end{array}$ & $\begin{array}{c}110 \\
(19 \cdot 0)\end{array}$ & $\begin{array}{c}145 \\
(23 \cdot 8)\end{array}$ & $\begin{array}{c}142 \\
(21 \cdot 9)\end{array}$ & $\begin{array}{c}131 \\
(22 \cdot 8)\end{array}$ & $\begin{array}{c}134 \\
(22 \cdot 8)\end{array}$ & $\begin{array}{c}124 \\
(20 \cdot 4)\end{array}$ \\
\hline IMD quintile 3 & $\begin{array}{c}57 \\
(9 \cdot 9) \\
\end{array}$ & $\begin{array}{c}84 \\
(14 \cdot 6) \\
\end{array}$ & $\begin{array}{c}74 \\
(12 \cdot 8) \\
\end{array}$ & $\begin{array}{c}73 \\
(12 \cdot 0) \\
\end{array}$ & $\begin{array}{c}97 \\
(14 \cdot 9) \\
\end{array}$ & $\begin{array}{c}70 \\
(12 \cdot 2) \\
\end{array}$ & $\begin{array}{c}82 \\
(13 \cdot 9) \\
\end{array}$ & $\begin{array}{c}96 \\
(15 \cdot 8) \\
\end{array}$ \\
\hline IMD quintile 4 & $\begin{array}{c}103 \\
(17 \cdot 9) \\
\end{array}$ & $\begin{array}{c}86 \\
(14.9) \\
\end{array}$ & $\begin{array}{c}93 \\
(16 \cdot 1) \\
\end{array}$ & $\begin{array}{c}109 \\
(17 \cdot 9)\end{array}$ & $\begin{array}{c}123 \\
(19 \cdot 0) \\
\end{array}$ & $\begin{array}{c}94 \\
(16 \cdot 4) \\
\end{array}$ & $\begin{array}{c}88 \\
(14 \cdot 9) \\
\end{array}$ & $\begin{array}{c}117 \\
(19 \cdot 2) \\
\end{array}$ \\
\hline $\begin{array}{l}\text { IMD quintile } 5 \\
\text { (least deprived) }\end{array}$ & $\begin{array}{c}43 \\
(7 \cdot 5) \\
\end{array}$ & $\begin{array}{c}38 \\
(6 \cdot 6) \\
\end{array}$ & $\begin{array}{c}45 \\
(7 \cdot 8) \\
\end{array}$ & $\begin{array}{c}45 \\
(7 \cdot 4) \\
\end{array}$ & $\begin{array}{c}55 \\
(8 \cdot 5) \\
\end{array}$ & $\begin{array}{c}60 \\
(10 \cdot 5) \\
\end{array}$ & $\begin{array}{c}63 \\
(10 \cdot 7) \\
\end{array}$ & $\begin{array}{c}45 \\
(7 \cdot 4) \\
\end{array}$ \\
\hline $\begin{array}{l}\text { IMD quintile } \\
\text { unknown }\end{array}$ & $\begin{array}{c}6 \\
(1 \cdot 0)\end{array}$ & $\begin{array}{c}10 \\
(1 \cdot 7)\end{array}$ & $\begin{array}{c}24 \\
(4 \cdot 2)\end{array}$ & $\begin{array}{c}4 \\
(0 \cdot 7)\end{array}$ & $\begin{array}{c}2 \\
(0 \cdot 3)\end{array}$ & $\begin{array}{c}4 \\
(0 \cdot 7)\end{array}$ & $\begin{array}{c}5 \\
(0 \cdot 8)\end{array}$ & $\begin{array}{c}2 \\
(0 \cdot 3)\end{array}$ \\
\hline \multicolumn{9}{|c|}{ Linear trend: $\chi^{2}(1)=9 \cdot 6 ; p=0 \cdot 002$ (excluding IMD unknown) } \\
\hline \multicolumn{9}{|l|}{ Performance status } \\
\hline PS 0 & $\begin{array}{c}54 \\
(9 \cdot 4) \\
\end{array}$ & $\begin{array}{c}60 \\
(10 \cdot 4) \\
\end{array}$ & $\begin{array}{c}42 \\
(7 \cdot 3) \\
\end{array}$ & $\begin{array}{c}56 \\
(9 \cdot 2) \\
\end{array}$ & $\begin{array}{c}59 \\
(9 \cdot 1) \\
\end{array}$ & $\begin{array}{c}55 \\
(9 \cdot 6) \\
\end{array}$ & $\begin{array}{c}58 \\
(9 \cdot 8) \\
\end{array}$ & $\begin{array}{c}34 \\
(5 \cdot 6) \\
\end{array}$ \\
\hline PS 1 & $\begin{array}{c}193 \\
(33 \cdot 4) \\
\end{array}$ & $\begin{array}{c}164 \\
(28 \cdot 5) \\
\end{array}$ & $\begin{array}{c}169 \\
(29 \cdot 2) \\
\end{array}$ & $\begin{array}{c}165 \\
(27 \cdot 1) \\
\end{array}$ & $\begin{array}{c}227 \\
(35 \cdot 0) \\
\end{array}$ & $\begin{array}{c}160 \\
(27 \cdot 9) \\
\end{array}$ & $\begin{array}{c}180 \\
(30 \cdot 6) \\
\end{array}$ & $\begin{array}{c}221 \\
(36 \cdot 3) \\
\end{array}$ \\
\hline PS 2 & $\begin{array}{c}119 \\
(20 \cdot 6) \\
\end{array}$ & $\begin{array}{c}114 \\
(19 \cdot 8) \\
\end{array}$ & $\begin{array}{c}123 \\
(21 \cdot 3) \\
\end{array}$ & $\begin{array}{c}141 \\
(23 \cdot 2)\end{array}$ & $\begin{array}{c}131 \\
(20 \cdot 2) \\
\end{array}$ & $\begin{array}{c}152 \\
(26 \cdot 5) \\
\end{array}$ & $\begin{array}{c}130 \\
(22 \cdot 1) \\
\end{array}$ & $\begin{array}{c}127 \\
(20 \cdot 9) \\
\end{array}$ \\
\hline PS 3 & $\begin{array}{c}142 \\
(24 \cdot 6)\end{array}$ & $\begin{array}{c}151 \\
(26 \cdot 2)\end{array}$ & $\begin{array}{c}161 \\
(27 \cdot 9)\end{array}$ & $\begin{array}{c}158 \\
(26 \cdot 0)\end{array}$ & $\begin{array}{c}158 \\
(24 \cdot 3)\end{array}$ & $\begin{array}{c}150 \\
(26 \cdot 1)\end{array}$ & $\begin{array}{c}154 \\
(26 \cdot 1)\end{array}$ & $\begin{array}{c}164 \\
(27 \cdot 0)\end{array}$ \\
\hline PS 4 & $\begin{array}{c}62 \\
(10 \cdot 7)\end{array}$ & $\begin{array}{c}78 \\
(13 \cdot 5)\end{array}$ & $\begin{array}{c}75 \\
(13 \cdot 0)\end{array}$ & $\begin{array}{c}76 \\
(12 \cdot 5)\end{array}$ & $\begin{array}{c}69 \\
(10 \cdot 6)\end{array}$ & $\begin{array}{c}52 \\
(9 \cdot 1)\end{array}$ & $\begin{array}{c}60 \\
(10 \cdot 2)\end{array}$ & $\begin{array}{c}57 \\
(9 \cdot 4)\end{array}$ \\
\hline PS unknown & $\begin{array}{c}7 \\
(1 \cdot 2) \\
\end{array}$ & $\begin{array}{c}9 \\
(1 \cdot 6) \\
\end{array}$ & $\begin{array}{c}8 \\
(1.4) \\
\end{array}$ & $\begin{array}{c}12 \\
(2 \cdot 0) \\
\end{array}$ & $\begin{array}{c}5 \\
(0 \cdot 8) \\
\end{array}$ & $\begin{array}{c}5 \\
(0 \cdot 9) \\
\end{array}$ & $\begin{array}{c}7 \\
(1 \cdot 2) \\
\end{array}$ & $\begin{array}{c}5 \\
(0 \cdot 8) \\
\end{array}$ \\
\hline
\end{tabular}

Table 2: Number, sex, age and quintile of deprivation for patients diagnosed with lung cancer at Leeds Teaching Hospitals 2008-2015.

All data presented as number of cases with percentage of total in parentheses. Changes over the eight calendar years were assessed by Chi-square test with one degree of freedom. 


\begin{tabular}{|c|c|c|c|c|c|c|c|c|}
\hline & \multicolumn{3}{|c|}{ Pre-campaign } & \multicolumn{2}{|c|}{ Early campaign } & \multicolumn{3}{|c|}{ Established campaign } \\
\hline $\begin{array}{l}\text { Year of lung cancer } \\
\text { diagnosis }\end{array}$ & 2008 & 2009 & 2010 & 2011 & 2012 & 2013 & 2014 & 2015 \\
\hline \multicolumn{9}{|c|}{ Stage (TNM 7th edition) } \\
\hline Stage I & $\begin{array}{c}96 \\
(16 \cdot 6)\end{array}$ & $\begin{array}{c}87 \\
(15 \cdot 1)\end{array}$ & $\begin{array}{c}111 \\
(19 \cdot 2)\end{array}$ & $\begin{array}{c}111 \\
(18 \cdot 3)\end{array}$ & $\begin{array}{c}132 \\
(20 \cdot 3)\end{array}$ & $\begin{array}{c}141 \\
(24 \cdot 6)\end{array}$ & $\begin{array}{c}155 \\
(26 \cdot 3)\end{array}$ & $\begin{array}{c}149 \\
(24 \cdot 5)\end{array}$ \\
\hline Stage II & $\begin{array}{c}50 \\
(8 \cdot 7)\end{array}$ & $\begin{array}{c}63 \\
(10 \cdot 9) \\
\end{array}$ & $\begin{array}{c}51 \\
(8 \cdot 8)\end{array}$ & $\begin{array}{c}58 \\
(9 \cdot 5) \\
\end{array}$ & $\begin{array}{c}58 \\
(8 \cdot 9) \\
\end{array}$ & $\begin{array}{c}54 \\
(9 \cdot 4) \\
\end{array}$ & $\begin{array}{c}63 \\
(10 \cdot 7)\end{array}$ & $\begin{array}{c}64 \\
(10 \cdot 5) \\
\end{array}$ \\
\hline Stage III & $\begin{array}{c}129 \\
(22 \cdot 4)\end{array}$ & $\begin{array}{c}136 \\
(23 \cdot 6)\end{array}$ & $\begin{array}{c}120 \\
(20 \cdot 8)\end{array}$ & $\begin{array}{c}123 \\
(20 \cdot 2)\end{array}$ & $\begin{array}{c}147 \\
(22 \cdot 7)\end{array}$ & $\begin{array}{c}114 \\
(19.9)\end{array}$ & $\begin{array}{c}113 \\
(19 \cdot 2)\end{array}$ & $\begin{array}{c}117 \\
(19 \cdot 2)\end{array}$ \\
\hline Stage IV & $\begin{array}{c}295 \\
(51 \cdot 1)\end{array}$ & $\begin{array}{c}284 \\
(49 \cdot 3)\end{array}$ & $\begin{array}{c}290 \\
(50 \cdot 2) \\
\end{array}$ & $\begin{array}{c}307 \\
(50 \cdot 5) \\
\end{array}$ & $\begin{array}{c}309 \\
(47 \cdot 6)\end{array}$ & $\begin{array}{c}264 \\
(46 \cdot 0) \\
\end{array}$ & $\begin{array}{c}256 \\
(43 \cdot 5)\end{array}$ & $\begin{array}{c}273 \\
(44.9) \\
\end{array}$ \\
\hline Unknown stage & $\begin{array}{c}7 \\
(1 \cdot 2)\end{array}$ & $\begin{array}{c}6 \\
(1 \cdot 0)\end{array}$ & $\begin{array}{c}6 \\
(1 \cdot 0)\end{array}$ & $\begin{array}{c}9 \\
(1 \cdot 5)\end{array}$ & $\begin{array}{c}3 \\
(0 \cdot 5)\end{array}$ & $\begin{array}{c}1 \\
(0 \cdot 2)\end{array}$ & $\begin{array}{c}2 \\
(0 \cdot 3)\end{array}$ & $\begin{array}{c}5 \\
(0 \cdot 8)\end{array}$ \\
\hline \multicolumn{9}{|c|}{ Linear trend: $\chi^{2}(1)=32 \cdot 2 ; \mathrm{p}<0 \cdot 0001$ (excluding stage unknown) } \\
\hline \multicolumn{9}{|l|}{ Pathological subtype } \\
\hline Adenocarcinoma & $\begin{array}{c}117 \\
(20 \cdot 3)\end{array}$ & $\begin{array}{c}91 \\
(15 \cdot 8)\end{array}$ & $\begin{array}{c}128 \\
(22 \cdot 1) \\
\end{array}$ & $\begin{array}{c}122 \\
(20 \cdot 1)\end{array}$ & $\begin{array}{c}182 \\
(28 \cdot 0)\end{array}$ & $\begin{array}{c}198 \\
(34 \cdot 5) \\
\end{array}$ & $\begin{array}{c}181 \\
(30 \cdot 7)\end{array}$ & $\begin{array}{c}179 \\
(29 \cdot 4) \\
\end{array}$ \\
\hline $\begin{array}{l}\text { Squamous Cell } \\
\text { Carcinoma } \\
\end{array}$ & $\begin{array}{c}95 \\
(16 \cdot 5) \\
\end{array}$ & $\begin{array}{c}99 \\
(17 \cdot 2)\end{array}$ & $\begin{array}{c}113 \\
(19 \cdot 6) \\
\end{array}$ & $\begin{array}{c}130 \\
(21 \cdot 4)\end{array}$ & $\begin{array}{c}156 \\
(24 \cdot 0)\end{array}$ & $\begin{array}{c}107 \\
(18 \cdot 6) \\
\end{array}$ & $\begin{array}{c}120 \\
(20 \cdot 4)\end{array}$ & $\begin{array}{c}115 \\
(18 \cdot 9)\end{array}$ \\
\hline $\begin{array}{l}\text { Non-Small Cell Lung } \\
\text { Cancer NOS }\end{array}$ & $\begin{array}{c}72 \\
(12 \cdot 5)\end{array}$ & $\begin{array}{c}69 \\
(12 \cdot 0)\end{array}$ & $\begin{array}{c}48 \\
(8 \cdot 3)\end{array}$ & $\begin{array}{c}59 \\
(9.7)\end{array}$ & $\begin{array}{c}47 \\
(7 \cdot 2)\end{array}$ & $\begin{array}{c}28 \\
(4 \cdot 9)\end{array}$ & $\begin{array}{c}22 \\
(3 \cdot 7)\end{array}$ & $\begin{array}{c}33 \\
(5 \cdot 4)\end{array}$ \\
\hline Large Cell Carcinoma & $\begin{array}{c}26 \\
(4 \cdot 5)\end{array}$ & $\begin{array}{c}43 \\
(7 \cdot 5)\end{array}$ & $\begin{array}{c}26 \\
(4 \cdot 5) \\
\end{array}$ & $\begin{array}{c}21 \\
(3 \cdot 5)\end{array}$ & $\begin{array}{c}13 \\
(2 \cdot 0) \\
\end{array}$ & $\begin{array}{c}12 \\
(2 \cdot 1)\end{array}$ & $\begin{array}{c}13 \\
(2 \cdot 2) \\
\end{array}$ & $\begin{array}{c}13 \\
(2 \cdot 1)\end{array}$ \\
\hline Small Cell Carcinoma & $\begin{array}{c}81 \\
(14 \cdot 0) \\
\end{array}$ & $\begin{array}{c}72 \\
(12 \cdot 5) \\
\end{array}$ & $\begin{array}{c}68 \\
(11 \cdot 8) \\
\end{array}$ & $\begin{array}{c}74 \\
(12 \cdot 2) \\
\end{array}$ & $\begin{array}{c}75 \\
(11 \cdot 6)\end{array}$ & $\begin{array}{c}55 \\
(9.6) \\
\end{array}$ & $\begin{array}{c}64 \\
(10 \cdot 9) \\
\end{array}$ & $\begin{array}{c}81 \\
(13 \cdot 3) \\
\end{array}$ \\
\hline Carcinoid & $\begin{array}{c}5 \\
(0.9)\end{array}$ & $\begin{array}{c}3 \\
(0 \cdot 5) \\
\end{array}$ & $\begin{array}{c}3 \\
(0 \cdot 5) \\
\end{array}$ & $\begin{array}{c}4 \\
(0.7) \\
\end{array}$ & $\begin{array}{c}8 \\
(1 \cdot 3)\end{array}$ & $\begin{array}{c}5 \\
(0 \cdot 9) \\
\end{array}$ & $\begin{array}{c}5 \\
(0 \cdot 8) \\
\end{array}$ & $\begin{array}{c}6 \\
(1 \cdot 0) \\
\end{array}$ \\
\hline Unknown & $\begin{array}{c}181 \\
(31 \cdot 4)\end{array}$ & $\begin{array}{c}199 \\
(34 \cdot 5)\end{array}$ & $\begin{array}{c}192 \\
(33 \cdot 2)\end{array}$ & $\begin{array}{c}198 \\
(32 \cdot 6)\end{array}$ & $\begin{array}{c}168 \\
(25 \cdot 9)\end{array}$ & $\begin{array}{c}169 \\
(29 \cdot 4)\end{array}$ & $\begin{array}{c}184 \\
(31 \cdot 2)\end{array}$ & $\begin{array}{c}181 \\
(29 \cdot 8)\end{array}$ \\
\hline \multicolumn{9}{|c|}{$\begin{array}{l}\text { Linear trends (all analyses excluding unknown) } \\
\text { Adenocarcinoma vs other types: } \chi^{2}(1)=60 \cdot 8 ; \mathrm{p}<0 \cdot 0001 \\
\text { Squamous Cell Carcinoma vs other types: } \chi^{2}(1)=0 \cdot 9 ; \mathrm{p}=0 \cdot 33 \\
\text { Non-Small Cell Lung Cancer NOS vs other types: } \chi^{2}(1)=58 \cdot 5 ; \mathrm{p}<0 \cdot 0001 \\
\text { Large Cell Carcinoma vs other types: } \chi^{2}(1)=30 \cdot 5 ; \mathrm{p}<0 \cdot 0001 \\
\text { Small Cell Carcinoma vs other types: } \chi^{2}(1)=2 \cdot 7 ; \mathrm{p}=0 \cdot 10 \\
\text { Carcinoid vs other types: } \chi^{2}(1)=0 \cdot 57 ; \mathrm{p}=0 \cdot 45\end{array}$} \\
\hline
\end{tabular}

Table 3: Stage distribution and pathological subtype of lung cancer for patients presenting to Leeds Teaching Hospitals 2008-2015.

All data presented as number of cases with percentage of total in parentheses. Changes over the eight calendar years were assessed by Chi-square test with one degree of freedom. 


\begin{tabular}{|c|c|c|c|c|c|c|c|c|}
\hline \multirow[b]{2}{*}{$\begin{array}{l}\text { Year of lung cancer } \\
\text { diagnosis }\end{array}$} & \multicolumn{3}{|c|}{ Pre-campaign } & \multicolumn{2}{|c|}{ Early campaign } & \multicolumn{3}{|c|}{ Established campaign } \\
\hline & 2008 & 2009 & 2010 & 2011 & 2012 & 2013 & 2014 & 2015 \\
\hline \multicolumn{9}{|l|}{ Route to diagnosis } \\
\hline Emergency presentation & $\begin{array}{c}214 \\
(37 \cdot 1) \\
\end{array}$ & $\begin{array}{c}201 \\
(34 \cdot 9) \\
\end{array}$ & $\begin{array}{c}208 \\
(36 \cdot 0) \\
\end{array}$ & $\begin{array}{c}192 \\
(31 \cdot 6) \\
\end{array}$ & $\begin{array}{c}183 \\
(28 \cdot 2) \\
\end{array}$ & $\begin{array}{c}162 \\
(28 \cdot 2) \\
\end{array}$ & $\begin{array}{c}171 \\
(29 \cdot 0) \\
\end{array}$ & $\begin{array}{c}177 \\
(29 \cdot 1) \\
\end{array}$ \\
\hline $\begin{array}{l}\text { Clinic referral (Fast- } \\
\text { track/Respiratory) }\end{array}$ & $\begin{array}{c}213 \\
(36 \cdot 9) \\
\end{array}$ & $\begin{array}{c}204 \\
(35 \cdot 4) \\
\end{array}$ & $\begin{array}{c}218 \\
(37 \cdot 7)\end{array}$ & $\begin{array}{c}252 \\
(41 \cdot 4)\end{array}$ & $\begin{array}{c}310 \\
(47 \cdot 8)\end{array}$ & $\begin{array}{c}272 \\
(47 \cdot 4) \\
\end{array}$ & $\begin{array}{c}298 \\
(50 \cdot 6) \\
\end{array}$ & $\begin{array}{c}306 \\
(50 \cdot 3) \\
\end{array}$ \\
\hline Intra-hospital referral & $\begin{array}{c}119 \\
(20 \cdot 6)\end{array}$ & $\begin{array}{c}148 \\
(25 \cdot 7) \\
\end{array}$ & $\begin{array}{c}125 \\
(21 \cdot 6) \\
\end{array}$ & $\begin{array}{c}133 \\
(21 \cdot 9) \\
\end{array}$ & $\begin{array}{c}116 \\
(17 \cdot 9) \\
\end{array}$ & $\begin{array}{c}90 \\
(15 \cdot 7) \\
\end{array}$ & $\begin{array}{c}69 \\
(11 \cdot 7) \\
\end{array}$ & $\begin{array}{c}75 \\
(12 \cdot 3) \\
\end{array}$ \\
\hline $\begin{array}{l}\text { Other (nodule/ } \\
\text { pneumonia) }\end{array}$ & $\begin{array}{c}29 \\
(5 \cdot 0) \\
\end{array}$ & $\begin{array}{c}20 \\
(3 \cdot 5) \\
\end{array}$ & $\begin{array}{c}24 \\
(4 \cdot 2) \\
\end{array}$ & $\begin{array}{c}29 \\
(4 \cdot 8) \\
\end{array}$ & $\begin{array}{c}38 \\
(5 \cdot 9) \\
\end{array}$ & $\begin{array}{c}49 \\
(8 \cdot 5) \\
\end{array}$ & $\begin{array}{c}48 \\
(8 \cdot 1) \\
\end{array}$ & $\begin{array}{c}47 \\
(7 \cdot 7) \\
\end{array}$ \\
\hline Unknown & $\begin{array}{c}2 \\
(0 \cdot 3)\end{array}$ & $\begin{array}{c}3 \\
(0 \cdot 5) \\
\end{array}$ & $\begin{array}{c}3 \\
(0 \cdot 5) \\
\end{array}$ & $\begin{array}{c}2 \\
(0 \cdot 3) \\
\end{array}$ & $\begin{array}{c}2 \\
(0 \cdot 3) \\
\end{array}$ & $\begin{array}{c}1 \\
(0 \cdot 2)\end{array}$ & $\begin{array}{c}3 \\
(0 \cdot 5) \\
\end{array}$ & $\begin{array}{c}3 \\
(0 \cdot 5) \\
\end{array}$ \\
\hline \multicolumn{9}{|c|}{$\begin{array}{l}\text { Linear trends (all analyses excluding unknown) } \\
\text { Emergency presentation vs other routes: } \chi^{2}(1)=20 \cdot 1 ; p<0 \cdot 001 \\
\text { Clinic referral vs other routes: } \chi^{2}(1)=60 \cdot 0 ; p<0 \cdot 001 \\
\text { Intra-hospital referral vs other routes: } \chi^{2}(1)=52 \cdot 6 ; p<0 \cdot 001 \\
\text { Other (nodule/pneumonia) vs other routes: } \chi^{2}(1)=19 \cdot 8 ; p<0 \cdot 001\end{array}$} \\
\hline \multicolumn{9}{|l|}{ Treatment } \\
\hline Surgical resection & $\begin{array}{c}77 \\
(13 \cdot 2) \\
\end{array}$ & $\begin{array}{c}81 \\
(14 \cdot 1) \\
\end{array}$ & $\begin{array}{c}68 \\
(11 \cdot 8) \\
\end{array}$ & $\begin{array}{c}84 \\
(13 \cdot 8) \\
\end{array}$ & $\begin{array}{c}106 \\
(16 \cdot 3) \\
\end{array}$ & $\begin{array}{c}95 \\
(16 \cdot 6) \\
\end{array}$ & $\begin{array}{c}105 \\
(17 \cdot 8)\end{array}$ & $\begin{array}{c}85 \\
(13 \cdot 8) \\
\end{array}$ \\
\hline $\begin{array}{l}\text { Radical oncological } \\
\text { treatment }\end{array}$ & $\begin{array}{c}21 \\
(3 \cdot 6) \\
\end{array}$ & $\begin{array}{c}41 \\
(7 \cdot 1) \\
\end{array}$ & $\begin{array}{c}67 \\
(11 \cdot 6) \\
\end{array}$ & $\begin{array}{c}71 \\
(11 \cdot 7) \\
\end{array}$ & $\begin{array}{c}92 \\
(14 \cdot 2) \\
\end{array}$ & $\begin{array}{c}92 \\
(16 \cdot 0) \\
\end{array}$ & $\begin{array}{c}86 \\
(14 \cdot 6) \\
\end{array}$ & $\begin{array}{c}102 \\
(16 \cdot 8) \\
\end{array}$ \\
\hline Palliative oncology & $\begin{array}{c}204 \\
(35 \cdot 4)\end{array}$ & $\begin{array}{c}199 \\
(34 \cdot 5)\end{array}$ & $\begin{array}{c}189 \\
(32 \cdot 7)\end{array}$ & $\begin{array}{c}220 \\
(36 \cdot 2)\end{array}$ & $\begin{array}{c}238 \\
(36 \cdot 7)\end{array}$ & $\begin{array}{c}193 \\
(33 \cdot 6)\end{array}$ & $\begin{array}{c}203 \\
(34 \cdot 5)\end{array}$ & $\begin{array}{c}208 \\
(34 \cdot 2)\end{array}$ \\
\hline Best supportive care & $\begin{array}{c}274 \\
(47 \cdot 5)\end{array}$ & $\begin{array}{c}254 \\
(44 \cdot 1)\end{array}$ & $\begin{array}{c}253 \\
(43 \cdot 8)\end{array}$ & $\begin{array}{c}232 \\
(38 \cdot 2)\end{array}$ & $\begin{array}{c}210 \\
(32 \cdot 4)\end{array}$ & $\begin{array}{c}194 \\
(33 \cdot 8)\end{array}$ & $\begin{array}{c}189 \\
(32 \cdot 1)\end{array}$ & $\begin{array}{c}213 \\
(35 \cdot 0)\end{array}$ \\
\hline Other & $\begin{array}{c}2 \\
(0 \cdot 3)\end{array}$ & $\begin{array}{c}1 \\
(0 \cdot 2)\end{array}$ & $\begin{array}{c}1 \\
(0 \cdot 2)\end{array}$ & $\begin{array}{c}1 \\
(0 \cdot 2)\end{array}$ & $\begin{array}{c}3 \\
(0 \cdot 5)\end{array}$ & $\begin{array}{c}0 \\
(0 \cdot 0)\end{array}$ & $\begin{array}{c}6 \\
(1 \cdot 0)\end{array}$ & $\begin{array}{c}1 \\
(0 \cdot 2)\end{array}$ \\
\hline
\end{tabular}

Table 4: Route to diagnosis and treatment of lung cancer for patients presenting to Leeds Teaching Hospitals 2008-2015.

All data presented as number of cases with percentage of total in parentheses. Changes over the eight calendar years were assessed by Chi-square test with one degree of freedom. 


\begin{tabular}{|l|c|c|c|c|c|c|c|c|}
\hline & \multicolumn{3}{|c|}{ Pre-campaign } & \multicolumn{2}{c|}{ Early campaign } & \multicolumn{2}{c|}{ Established campaign } \\
\hline $\begin{array}{l}\text { Year of lung cancer } \\
\text { diagnosis }\end{array}$ & 2008 & 2009 & 2010 & 2011 & 2012 & 2013 & 2014 & 2015 \\
\hline $\begin{array}{l}\text { Median survival } \\
\text { (days) }\end{array}$ & 163 & 191 & 155 & 196 & 242 & 211 & 276 & 240 \\
\hline One year survival (\%) & $\begin{array}{c}175 \\
(30 \cdot 3)\end{array}$ & $\begin{array}{c}199 \\
(34 \cdot 5)\end{array}$ & $\begin{array}{c}176 \\
(30 \cdot 4)\end{array}$ & $\begin{array}{c}214 \\
(35 \cdot 2)\end{array}$ & $\begin{array}{c}256 \\
(39 \cdot 4)\end{array}$ & $\begin{array}{c}225 \\
(39 \cdot 2)\end{array}$ & $\begin{array}{c}250 \\
(42 \cdot 4)\end{array}$ & $\begin{array}{c}238 \\
(39 \cdot 1)\end{array}$ \\
\hline
\end{tabular}

Table 5: Lung cancer survival for patient presenting to Leeds Teaching Hospitals 2008-2015.

One year survival data presented as number of cases with percentage of total in parentheses. Changes over the eight calendar years were assessed by Chi-square test with one degree of freedom. 


\begin{tabular}{|c|c|c|c|c|c|c|c|c|c|}
\hline Year & 2008 & 2009 & 2010 & 2011 & 2012 & 2013 & 2014 & 2015 & 2016 \\
\hline $\begin{array}{l}\text { Lung cancer deaths England \& } \\
\text { Wales }\end{array}$ & 30,326 & 30,018 & 29,977 & 30,148 & 30,273 & 30,437 & 30,868 & 30,520 & 30,570 \\
\hline $\begin{array}{l}\text { Lung cancer age-standardised } \\
\text { mortality rate England \& Wales } \\
\text { per } 100,000 \text { population } \\
(95 \% \mathrm{CI})\end{array}$ & $\begin{array}{c}64 \cdot 4 \\
(63 \cdot 7- \\
65 \cdot 1)\end{array}$ & $\begin{array}{c}62 \cdot 8 \\
(62 \cdot 1- \\
63 \cdot 5)\end{array}$ & $\begin{array}{c}61 \cdot 8 \\
(61 \cdot 1- \\
62 \cdot 5)\end{array}$ & $\begin{array}{c}61 \cdot 3 \\
(60 \cdot 6- \\
62 \cdot 0)\end{array}$ & $\begin{array}{c}60 \cdot 4 \\
(59 \cdot 7- \\
61 \cdot 0)\end{array}$ & $\begin{array}{c}59 \cdot 7 \\
(59 \cdot 0- \\
60 \cdot 4)\end{array}$ & $\begin{array}{c}59 \cdot 3 \\
(58 \cdot 7- \\
60 \cdot 0)\end{array}$ & $\begin{array}{c}57 \cdot 8 \\
(57 \cdot 1- \\
58 \cdot 4)\end{array}$ & $\begin{array}{r}56 \cdot 9 \\
(56 \cdot 3- \\
57 \cdot 6)\end{array}$ \\
\hline Lung cancer deaths Leeds & 532 & 475 & 509 & 478 & 480 & 502 & 454 & 455 & 464 \\
\hline $\begin{array}{l}\text { Lung cancer age-standardised } \\
\text { mortality rate Leeds per } \\
100,000 \text { population } \\
(95 \% \text { CI })\end{array}$ & $\begin{array}{r}92 \cdot 7 \\
(84 \cdot 8- \\
100 \cdot 6)\end{array}$ & $\begin{array}{c}82 \cdot 0 \\
(74 \cdot 6- \\
89 \cdot 4)\end{array}$ & $\begin{array}{c}86 \cdot 8 \\
(79 \cdot 2- \\
94 \cdot 4)\end{array}$ & $\begin{array}{c}81 \cdot 7 \\
(74 \cdot 4- \\
89 \cdot 1)\end{array}$ & $\begin{array}{l}80 \cdot 8 \\
(73 \cdot 5- \\
88 \cdot 1)\end{array}$ & $\begin{array}{c}83 \cdot 6 \\
(76 \cdot 3- \\
91 \cdot 0)\end{array}$ & $\begin{array}{c}75 \cdot 0 \\
(68 \cdot 1- \\
82 \cdot 0)\end{array}$ & $\begin{array}{c}74 \cdot 1 \\
(67 \cdot 3- \\
81 \cdot 0)\end{array}$ & $\begin{array}{c}75 \cdot 0 \\
(68 \cdot 1- \\
81 \cdot 8)\end{array}$ \\
\hline
\end{tabular}

Table 6: The numbers of deaths where the underlying cause was lung cancer (ICD-10 C33-C34) and the corresponding age-standardised mortality rate per 100,000 population for England and Wales and the geographical area defined by the May 2013 boundaries of the three Leeds Clinical Commissioning Groups from 2008 to 2016 (Source: Office for National Statistics) ${ }^{11}$ 


\begin{tabular}{|c|c|c|c|c|c|c|c|c|c|}
\hline $\begin{array}{l}\text { Year of lung } \\
\text { cancer diagnosis }\end{array}$ & 2008 & 2009 & 2010 & 2011 & 2012 & 2013 & 2014 & 2015 & 2016 \\
\hline \multicolumn{10}{|c|}{ Leeds Teaching Hospitals } \\
\hline Stage I+II & $\begin{array}{c}146 \\
(25 \cdot 3) \\
\end{array}$ & $\begin{array}{c}150 \\
(26 \cdot 0) \\
\end{array}$ & $\begin{array}{c}162 \\
(28 \cdot 0) \\
\end{array}$ & $\begin{array}{c}169 \\
(27 \cdot 8) \\
\end{array}$ & $\begin{array}{c}190 \\
(29 \cdot 3) \\
\end{array}$ & $\begin{array}{c}195 \\
(34 \cdot 0) \\
\end{array}$ & $\begin{array}{c}218 \\
(37 \cdot 0) \\
\end{array}$ & $\begin{array}{c}213 \\
(35 \cdot 0) \\
\end{array}$ & $\begin{array}{c}230 * \\
(37 \cdot 2) \\
\end{array}$ \\
\hline Stage III+IV & $\begin{array}{c}424 \\
(73 \cdot 5)\end{array}$ & $\begin{array}{c}420 \\
(72 \cdot 9)\end{array}$ & $\begin{array}{c}410 \\
(70 \cdot 9)\end{array}$ & $\begin{array}{l}430 \\
(70 \cdot 7)\end{array}$ & $\begin{array}{c}456 \\
(70 \cdot 3)\end{array}$ & $\begin{array}{c}378 \\
(65 \cdot 9)\end{array}$ & $\begin{array}{c}369 \\
(62 \cdot 6)\end{array}$ & $\begin{array}{c}390 \\
(64 \cdot 1)\end{array}$ & $\begin{array}{c}375^{*} \\
(60 \cdot 6)\end{array}$ \\
\hline Stage Unknown & $\begin{array}{c}7 \\
(1 \cdot 2)\end{array}$ & $\begin{array}{c}6 \\
(1 \cdot 0) \\
\end{array}$ & $\begin{array}{c}6 \\
(1 \cdot 0) \\
\end{array}$ & $\begin{array}{c}9 \\
(1 \cdot 5) \\
\end{array}$ & $\begin{array}{c}3 \\
(0 \cdot 5) \\
\end{array}$ & $\begin{array}{c}1 \\
(0 \cdot 2)\end{array}$ & $\begin{array}{c}2 \\
(0 \cdot 3)\end{array}$ & $\begin{array}{c}5 \\
(0 \cdot 8) \\
\end{array}$ & $\begin{array}{c}14 * \\
(2 \cdot 3)\end{array}$ \\
\hline Total & $\begin{array}{c}577 \\
(100 \cdot 0) \\
\end{array}$ & $\begin{array}{c}576 \\
(100 \cdot 0) \\
\end{array}$ & $\begin{array}{c}578 \\
(100 \cdot 0) \\
\end{array}$ & $\begin{array}{c}608 \\
(100 \cdot 0) \\
\end{array}$ & $\begin{array}{c}649 \\
(100 \cdot 0) \\
\end{array}$ & $\begin{array}{c}574 \\
(100 \cdot 0) \\
\end{array}$ & $\begin{array}{c}589 \\
(100 \cdot 0) \\
\end{array}$ & $\begin{array}{c}608 \\
(100 \cdot 0) \\
\end{array}$ & $\begin{array}{c}619 * \\
(100 \cdot 0)\end{array}$ \\
\hline $\begin{array}{l}\text { Proportion Stage } \\
\text { I+II of those with } \\
\text { TNM stage }(\%)\end{array}$ & $25 \cdot .6$ & $26 \cdot 3$ & $28 \cdot 3$ & $28 \cdot 2$ & $29 \cdot 4$ & $34 \cdot 0$ & $37 \cdot 1$ & $35 \cdot 3$ & $38 \cdot 0^{*}$ \\
\hline \multicolumn{10}{|c|}{ National Lung Cancer Audit } \\
\hline Stage I+II & N/A & N/A & N/A & $\begin{array}{l}5,998 \\
(19 \cdot 0) \\
\end{array}$ & $\begin{array}{l}7,065 \\
(21 \cdot 4) \\
\end{array}$ & $\begin{array}{l}7,137 \\
(22 \cdot 0) \\
\end{array}$ & $\begin{array}{l}7,071 \\
(23 \cdot 5) \\
\end{array}$ & $\begin{array}{l}9,460 \\
(24 \cdot 7) \\
\end{array}$ & $\begin{array}{l}10,165 \\
(26 \cdot 0) \\
\end{array}$ \\
\hline Stage III+IV & N/A & N/A & N/A & $\begin{array}{l}19,264 \\
(60 \cdot 9)\end{array}$ & $\begin{array}{l}20,227 \\
(61 \cdot 2)\end{array}$ & $\begin{array}{l}19,607 \\
(60 \cdot 3)\end{array}$ & $\begin{array}{l}20,474 \\
(68 \cdot 2)\end{array}$ & $\begin{array}{l}26,871 \\
(70 \cdot 2)\end{array}$ & $\begin{array}{l}27,163 \\
(69 \cdot 6)\end{array}$ \\
\hline $\begin{array}{l}\text { Limited stage } \\
\text { Small Cell }\end{array}$ & N/A & N/A & N/A & $\begin{array}{l}1,038 \\
(3 \cdot 3)\end{array}$ & $\begin{array}{l}1,120 \\
(3 \cdot 4) \\
\end{array}$ & $\begin{array}{l}1,114 \\
(3 \cdot 4)\end{array}$ & $\begin{array}{c}0 \\
(0 \cdot 0) \\
\end{array}$ & $\begin{array}{c}0 \\
(0 \cdot 0)\end{array}$ & $\begin{array}{c}0 \\
(0 \cdot 0) \\
\end{array}$ \\
\hline $\begin{array}{l}\text { Extensive stage } \\
\text { Small Cell }\end{array}$ & N/A & N/A & N/A & $\begin{array}{l}2,481 \\
(7 \cdot 8) \\
\end{array}$ & $\begin{array}{c}2,424 \\
(7 \cdot 3) \\
\end{array}$ & $\begin{array}{c}2,413 \\
(7 \cdot 4) \\
\end{array}$ & $\begin{array}{c}0 \\
(0 \cdot 0) \\
\end{array}$ & $\begin{array}{c}0 \\
(0 \cdot 0) \\
\end{array}$ & $\begin{array}{c}0 \\
(0 \cdot 0) \\
\end{array}$ \\
\hline Stage Unknown & N/A & N/A & N/A & $\begin{array}{c}2,857 \\
(9 \cdot 0)\end{array}$ & $\begin{array}{c}2,199 \\
(6 \cdot 7)\end{array}$ & $\begin{array}{c}2,231 \\
(6 \cdot 9)\end{array}$ & $\begin{array}{c}2,481 \\
(8 \cdot 3)\end{array}$ & $\begin{array}{l}1,938 \\
(5 \cdot 1)\end{array}$ & $\begin{array}{l}1,710 \\
(4 \cdot 4)\end{array}$ \\
\hline Total & N/A & N/A & N/A & $\begin{array}{c}31,638 \\
(100 \cdot 0)\end{array}$ & $\begin{array}{l}33,035 \\
(100 \cdot 0)\end{array}$ & $\begin{array}{c}32,502 \\
(100 \cdot 0)\end{array}$ & $\begin{array}{c}30,026 \\
(100 \cdot 0)\end{array}$ & $\begin{array}{c}38,269 \\
(100 \cdot 0)\end{array}$ & $\begin{array}{l}39,038 \\
(100 \cdot 0)\end{array}$ \\
\hline $\begin{array}{l}\text { Proportion Stage } \\
\text { I+II of those with } \\
\text { TNM stage }(\%)\end{array}$ & N/A & N/A & N/A & $23 \cdot 7$ & $25 \cdot 9$ & $26 \cdot 7$ & $25 \cdot 7$ & $26 \cdot 0$ & $27 \cdot 2$ \\
\hline \multicolumn{10}{|c|}{ National Cancer Registration and Analysis Service } \\
\hline Stage I+II & N/A & N/A & N/A & $\begin{array}{l}5,057 \\
(14 \cdot 1) \\
\end{array}$ & $\begin{array}{r}7,560 \\
(20 \cdot 3) \\
\end{array}$ & $\begin{array}{l}7,591 \\
(20 \cdot 3) \\
\end{array}$ & $\begin{array}{l}8,574 \\
(22 \cdot 6) \\
\end{array}$ & $\begin{array}{c}9,068 \\
(24 \cdot 1) \\
\end{array}$ & N/A \\
\hline Stage III+IV & N/A & N/A & N/A & $\begin{array}{l}20,687 \\
(57 \cdot 7)\end{array}$ & $\begin{array}{l}25,045 \\
(67 \cdot 2)\end{array}$ & $\begin{array}{c}24,458 \\
(65 \cdot 4)\end{array}$ & $\begin{array}{l}25,382 \\
(67 \cdot 0)\end{array}$ & $\begin{array}{l}25,734 \\
(68 \cdot 4)\end{array}$ & N/A \\
\hline Stage Unknown & N/A & N/A & N/A & $\begin{array}{l}10,113 \\
(28 \cdot 2)\end{array}$ & $\begin{array}{l}4,647 \\
(12 \cdot 5) \\
\end{array}$ & $\begin{array}{l}5,363 \\
(14 \cdot 3)\end{array}$ & $\begin{array}{l}3,912 \\
(10 \cdot 3) \\
\end{array}$ & $\begin{array}{l}2,839 \\
(7 \cdot 5)\end{array}$ & N/A \\
\hline Total & N/A & N/A & N/A & $\begin{array}{c}35,857 \\
(100 \cdot 0)\end{array}$ & $\begin{array}{l}37,252 \\
(100 \cdot 0)\end{array}$ & $\begin{array}{c}37,412 \\
(100 \cdot 0)\end{array}$ & $\begin{array}{c}37,868 \\
(100 \cdot 0) \\
\end{array}$ & $\begin{array}{c}37,641 \\
(100 \cdot 0)\end{array}$ & N/A \\
\hline $\begin{array}{l}\text { Proportion Stage } \\
\text { I+II of those with } \\
\text { TNM stage }(\%)\end{array}$ & N/A & N/A & N/A & $19 \cdot 6$ & $23 \cdot 2$ & $23 \cdot 7$ & $25 \cdot 3$ & $26 \cdot 1$ & N/A \\
\hline
\end{tabular}

Table 7: Lung cancer stage distribution for patients first presenting to Leeds Teaching Hospitals, and all patients in England and Wales from the National Lung Cancer Audit, and National Cancer Registration and Analysis Service 2008-2016.

Except where otherwise stated, data presented as number of cases with percentage of total in parentheses. N/A indicates data not available. *Leeds Teaching Hospitals 2016 data taken directly from the National Lung Cancer Audit (not presented elsewhere in this paper). ${ }^{16}$ 


\section{Community-ordered chest X-rays in Leeds 2008-2015}

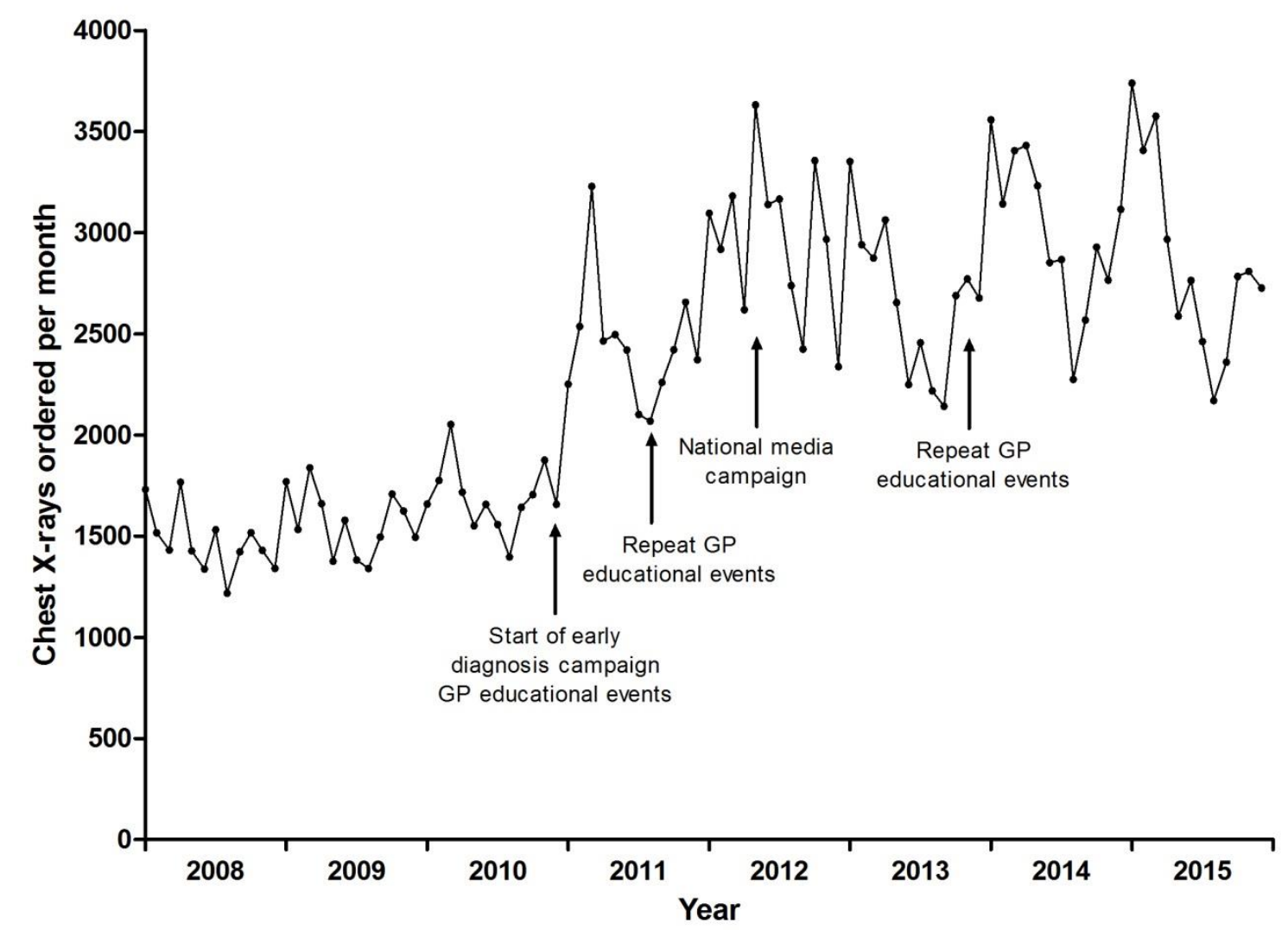

Figure 1: Number of community-ordered chest X-rays in Leeds per month from 2008-2015. GP, general practitioner. 
5,800 cases of lung cancer identified through National Lung Cancer Audit and National Cancer Registration and Analysis Service, diagnosed between January 2008 and December 2015, first seen at Leeds Teaching Hospitals

323 cases with pathological confirmation of non-lung cancer

20 cases deemed non-lung cancer following discussion at multi-disciplinary team meeting

698 cases first presenting to another hospital

4,759 cases included for analysis

Figure 2: Flowchart of cases identified from National Lung Cancer Audit and National Cancer Registration and Analysis Service, and those excluded from analysis for various reasons. 


\section{Lung cancer age-standardised mortality rates \\ for England and Wales vs. Leeds 2008-2016}

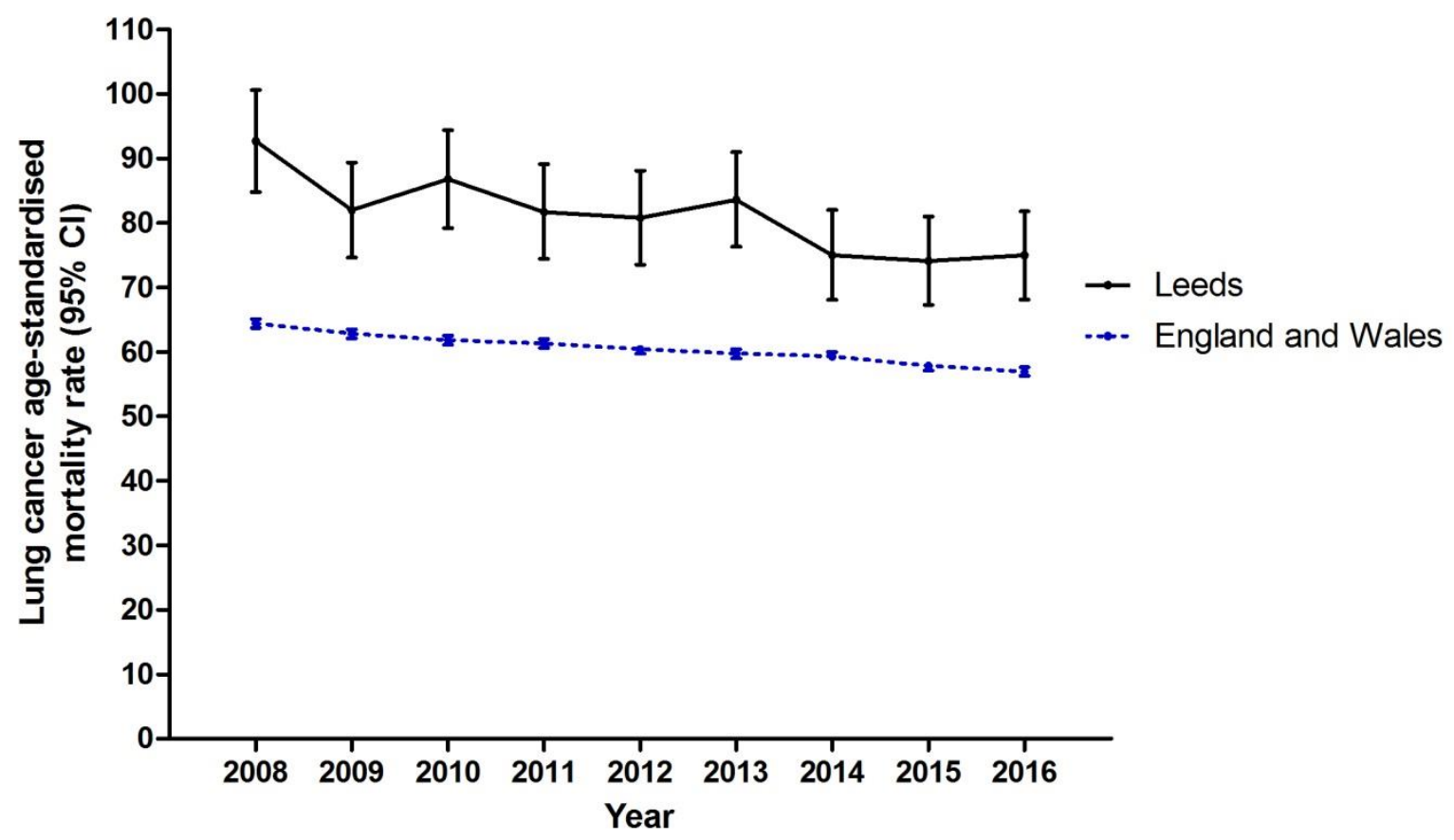

Figure 3: Lung cancer age-standardised mortality rates for England and Wales and the geographical area defined by the May 2013 boundaries of the three Leeds Clinical Commissioning Groups from 2008 to 2016. Source: Office for National Statistics. 


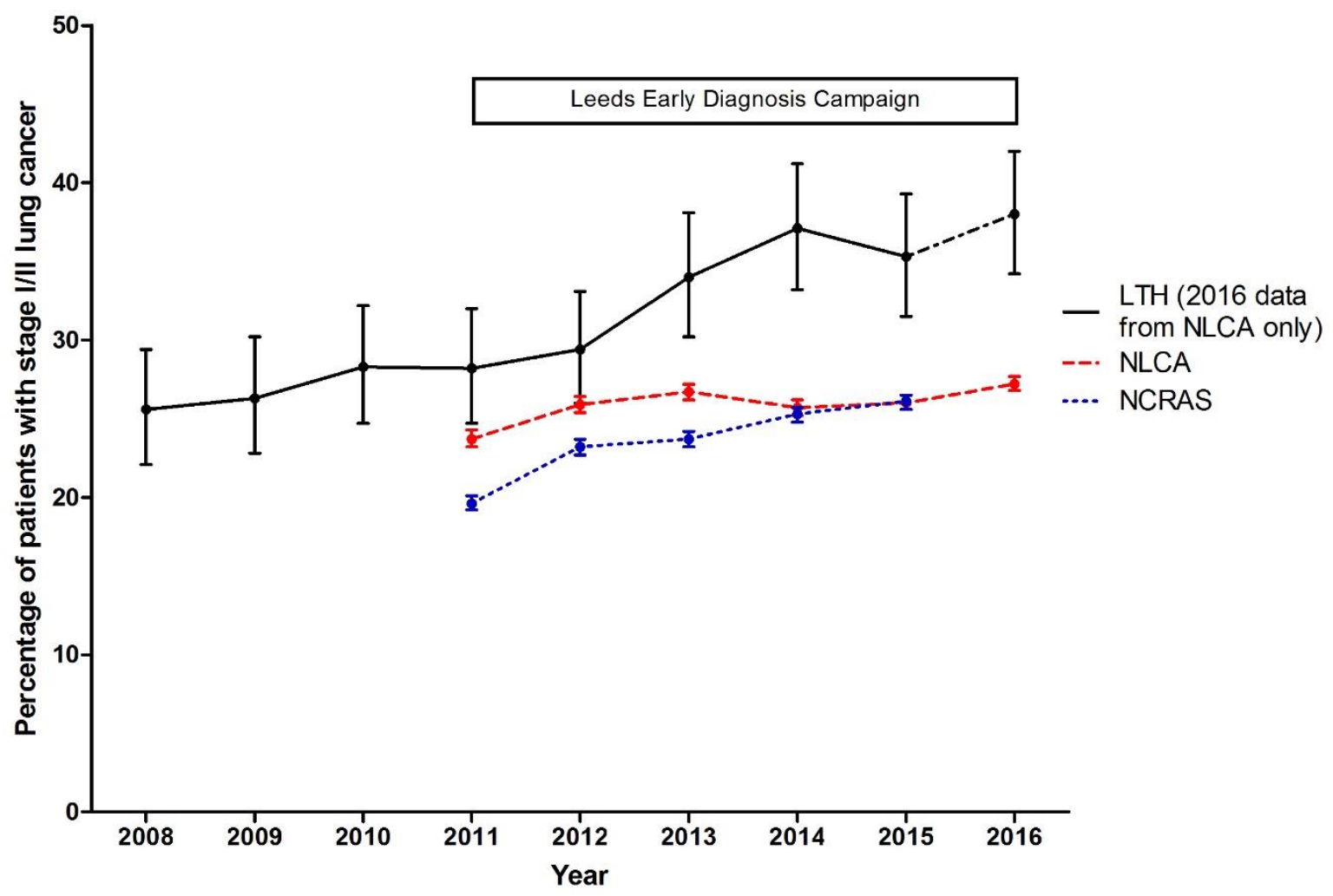

Figure 4: Percentage of patients with stage I/II lung cancer as a percentage of all those with a TNM stage from Leeds Teaching Hospitals (LTH), the National Lung Cancer Audit (NLCA) and the National Cancer Registration and Analysis Service (NCRAS) from 2008 to 2016. Leeds Teaching Hospitals 2016 data taken directly from the National Lung Cancer Audit (not presented elsewhere in this paper). 


\section{References}

1. Berrino F, De Angelis R, Sant M, Rosso S, Bielska-Lasota M, Coebergh JW, et al. Survival for eight major cancers and all cancers combined for European adults diagnosed in 1995-99: results of the EUROCARE-4 study. The Lancet Oncology. 2007; 8(9): 773-83.

2. Holmberg L, Sandin F, Bray F, Richards M, Spicer J, Lambe M, et al. National comparisons of lung cancer survival in England, Norway and Sweden 2001-2004: differences occur early in follow-up. Thorax. 2010; 65(5): 436-41.

3. Coleman MP, Forman D, Bryant H, Butler J, Rachet B, Maringe C, et al. Cancer survival in Australia, Canada, Denmark, Norway, Sweden, and the UK, 1995-2007 (the International Cancer Benchmarking Partnership): an analysis of population-based cancer registry data. Lancet. 2011; 377(9760): 127-38.

4. De Angelis R, Sant M, Coleman MP, Francisci S, Baili P, Pierannunzio D, et al. Cancer survival in Europe 1999-2007 by country and age: results of EUROCARE--5-a population-based study. The Lancet Oncology. 2014; 15(1): 23-34.

5. Walters S, Maringe C, Coleman MP, Peake MD, Butler J, Young N, et al. Lung cancer survival and stage at diagnosis in Australia, Canada, Denmark, Norway, Sweden and the UK: a population-based study, 2004-2007. Thorax. 2013; 68(6): 551-64.

6. Richards MA. The National Awareness and Early Diagnosis Initiative in England: assembling the evidence. British journal of cancer. 2009; 101 Suppl 2: S1-4.

7. Elliss-Brookes L, McPhail S, Ives A, Greenslade M, Shelton J, Hiom S, et al. Routes to diagnosis for cancer - determining the patient journey using multiple routine data sets. British journal of cancer. 2012; 107(8): 1220-6.

8. McPhail S, Elliss-Brookes L, Shelton J, Ives A, Greenslade M, Vernon S, et al. Emergency presentation of cancer and short-term mortality. British journal of cancer. 2013; 109(8): 2027-34.

9. Lung cancer: diagnosis and treatment. Clinical guideline [CG24]. London: National Institute for Clinical Excellence; 2005.

10. Khakwani A, Jack RH, Vernon S, Dickinson R, Wood N, Harden S, et al. Apples and pears? A comparison of two sources of national lung cancer audit data in England. ERJ open research. 2017; $3(3)$.

11. Number of deaths where the underlying cause of death was lung cancer in England and Wales, Leeds and Clinical Commissioning Groups in Leeds, 2001 to 2016 registrations. [cited 2018 7th February]; Available from: https://www.ons.gov.uk/peoplepopulationandcommunity/birthsdeathsandmarriages/deaths/adhocs/007 464numberofdeathswheretheunderlyingcauseofdeathwaslungcancerinenglandandwalesleedsandclinica lcommissioninggroupsinleeds2001to2016registrations

12. National Lung Cancer Audit annual report 2016 (for the audit period 2015). London: Royal College of Physicians; 2016.

13. Ironmonger L, Ohuma E, Ormiston-Smith $\mathrm{N}$, Gildea $\mathrm{C}$, Thomson CS, Peake MD. An evaluation of the impact of large-scale interventions to raise public awareness of a lung cancer symptom. British journal of cancer. 2015; 112(1): 207-16.

14. Routes to diagnosis 2006-2013, preliminary results. National Cancer Intelligence Network. Public Health England; 2015.

15. Walters S, Benitez-Majano S, Muller P, Coleman MP, Allemani C, Butler J, et al. Is England closing the international gap in cancer survival? British journal of cancer. 2015; 113(5): 848-60.

16. National Lung Cancer Audit annual report 2017 (for the audit period 2016). London: Royal College of Physicians; 2018.

17. Oken MM, Hocking WG, Kvale PA, Andriole GL, Buys SS, Church TR, et al. Screening by chest radiograph and lung cancer mortality: the Prostate, Lung, Colorectal, and Ovarian (PLCO) randomized trial. Jama. 2011; 306(17): 1865-73.

18. Biswas M, Ades AE, Hamilton W. Symptom lead times in lung and colorectal cancers: what are the benefits of symptom-based approaches to early diagnosis? British journal of cancer. 2015; 112(2): 271-7. 
19. Ades AE, Biswas M, Welton NJ, Hamilton W. Symptom lead time distribution in lung cancer: natural history and prospects for early diagnosis. International journal of epidemiology. 2014; 43(6): $1865-73$ 